\title{
Artificial Neural Network Application for Surface Roughness Prediction when Drilling Nickel Based Alloy
}

\author{
Ildikó Maňková ${ }^{1}$, Marek Vrabel ${ }^{1}$, Pavel Kovac ${ }^{2}$ \\ ${ }^{1}$ Technical University of Košice, Faculty of Mechanical Engineering, Department of Technology and Materials, \\ Mäsiarska 74, 04001 Košice, Slovakia, ildiko.mankova@tuke.sk, marek.vrabel@tuke.sk 22University of Novi Sad, Trg \\ D. Obradovica 6, 21000 Novi Sad, Serbia, pkovac@uns.ac.rs
}

Article deals with design of appropriate artificial neural network for prediction of surface roughness as one of the very important indicators of machined surface quality. The drilling of nickel based super alloy UDIMET 720, was applied as test material. This type of material is most frequently used for jet engines components such as discs etc. Experimental data collected from tests were used as input parameters into neural network to identify the sensitivity among cutting conditions, tool wear and monitoring parameters and surface roughness. Selected parameters were used to design a suitable algorithm for control and monitoring of the drilling process with respect on surface roughness. The accuracy of predicted and measured values are compared and discussed.

Keywords: artificial neural network, surface roughness prediction, nickel based alloy Udimet 720

\section{Acknowledgement}

This work was supported by the Slovak Research and Development Agency under the contract No DO7RP-0014-09 and granted research project VEGA 1/0279/11'Integration of trials, numerical simulation and neural network to predict cutting tool performance" as well as the APVV SK-SRB-0031-11 bilateral project.

\section{References}

[1] ECKSTEIN, M., MAŇKOVÁ, I. (2012). Monitoring of Drilling Process for Highly Stressed Aero engine Components. Proceedia CIRP 1 (2012), pp. 587-592.

[2] KLOCKE, F., GIERLINGS S., BROCKMANN M., SAGE C., VESELOVAC D. (2010). Adaptive Control of Manufacturing Processes for a New Generation of Jet Engine Components.7th CIRP-ICME Capri, pp.321-322.

[3] MRKVICA, I., NESLUŠAN, M., KONDERLA, R., JANOŠ, M.: Cutting ceramic by turning of nickel alloy Inconel. Manufacturing Technology, J. For Science, Res. and Production. December 2012, vol. 13, Ústi nad Labem, p. $178-186$, ISSN $1213-2489$

[4] KURT, A. (2009). Modelling of the Cutting Tool Stresses in Machining of Inconel 718 Using Artificial Neural Networks, Expert Systems with Applications 36 (2009) 9645 - 9657.

[5] UPADHYAY, V., JAIN P. K., MEHTA, N. K. (2012). In - process Prediction of Surface Roughness in Turning of Ti-6Al - 4V Alloy Using Cutting Parameters and Vibration Signals, Measurement 46 (2013) 154-160.

[6] BENARDOS, P.G., VOSNIAKOS, G.C. (2002). Prediction of surface roughness in CNC face milling using neural networks and Taguchi's design of experiments, Robot. Comput. Integr. Manuf. 18, 343-354.

[7] BENARDOS, P.G., VOSNIAKOS, G.C., (2003). Predicting surface roughness in machining: a review. Int. J. Mach. Tools Manuf. 43, 833-844.

[8] KARAYEL, D., Prediction and control of surface roughness in CNC lathe using artificial neural network, Journal of Materials Processing Technology 209 (2009), 3125 - 3137.

[9] RISBOOD, K. A., DIXIT, U. S., SAHASRABUDHE, A. D. (2003). Prediction of surface roughness and dimensional deviation by measuring cutting forces and vibrations in turning process, Journal of Materials Processing Technology 132 (2003), 203 - 214.

[10] ASILTURK, I., CUNKAS, M. (2011). Modelling and prediction of surface roughness in turning operations using artificial neural network and multiple regression method, Exp. Sys. with Applic. 38 (2011), 5826 - 5832.

[11] EZUGWU, E. O., FADARE, D. A, BONNEY J., da SILVA R. B., SALES W. F. (2005). Modelling the correlation between cutting and process parameters in high - speed machining of Iconel 718 alloy using and artificial neural network, International Journal of Machine Tools \& Manufacture 45 (2005), 1375 - 1385.

[12] TSAO, C. C., HOCHENG, H. (2008). Evaluation of thrust force and surface roughness in drilling composite material using Taguchi analysis and neural network, Jour. of Mater. Process. Techno. 203 (2008), 342 - 348. 
[13] DAVIM, P. J., GAITONDE V. N., KARNIK, S. R. (2008). Investigations into the effect of cutting conditions on surface roughness in turning of free machining steel by ANN models, Journal of Materials Processing Technology 205 (2008), $16-23$.

[14] ŠIPEK, M., ČILÍKOVÁ, M., NESLUŠAN, M.: Monitoring of tool wear with acoustic emission. Manufacturing Technology, Duben 2011, vol. XVI/2, Ústi nad Labem, p. 57 - 66

[15] DUTILH V., DESSEIN G., ALEXIS J., PERRIN G.(2010). Links between machining parameters and surface integrity in drilling Ni-superalloy, International Journal of Advanced Materials Research, vol.112, pp171-178, ISBN 0-87849-262-3.

[16] POPA A., DESSEIN G., BAILI M., DUTILH V. (2012). Investigation of Tool Failure Modes and Machining Disturbances Using Monitoring Signals, International Journal of Advanced Materials Research, vol. 423, 2012, pp128-142, ISSN 1022-6680. 